\title{
Relationship Among Intramammary Infection and Raw Milk Parameters in Jersey Crossbred Cows under Hot-Humid Climate
}

\author{
Pranay Bharti $^{1 *}$, Champak Bhakat ${ }^{2}$, M.K. Ghosh ${ }^{2}$, T.K. Dutta ${ }^{2}$ and Ramendra Das ${ }^{1}$ \\ ${ }^{1} I C A R$-National Dairy Research Institute, Karnal, INDIA \\ ${ }^{2}$ ICAR- National Dairy Research Institute (ERS), Kalyani, INDIA \\ *Corresponding author: P Bharti; Email:dr12pranay@gmail.com
}

Received: 07 December, 2014

Accepted: 27 May, 2015

\begin{abstract}
The raw milk quality has increasing importance for producer and consumer as it is directly related to processing, production and price. The aim of present study was to determine the relationship among intramammary infection (IMI) and raw milk parameters in Jersey crossbred cows. Total 24 lactating Jersey crossbred cows were randomly selected and representative animal wise morning milk samples were collected in monthly interval for four month. The level of somatic cell count (SCC) and milk parameters (fat (\%), solid non-fat (\%) and $\mathrm{pH}$ ) was estimated from the collected sample. Test day milk yield for individual animals was also recorded and then the data obtained were statistically analyzed. A significant $(\mathrm{P}<0.01)$ negative correlation of $\log _{10} \mathrm{SCC}$ with test day milk yield, fat and SNF percentage was found, while, milk pH was highly positive correlated with $\log _{10}$ SCC in milk. The mean \pm SE values of milk yield, fat and SNF were significantly $(\mathrm{P}<0.01)$ lower in subclinical infected group except for SCC and $\mathrm{pH}$, which were higher in subclinical infected group. It can be concluded that IMI and higher SCC adversely affect the milk production and raw milk quality parameters and these parameters can be used as useful indicator as complimentary to SCC to monitor udder health and for early diagnosis of subclinical mastitis at dairy farm.
\end{abstract}

Keywords: Intramammary Infection, Jersey crossbred, Raw milk Parameter, Relationship

Milk characteristics in terms of milk composition and milk yield are important factors for the dairy farmer, dairy industry and consumer. Mastitis is a serious disease of dairy animals causing great economic losses due to a reduction in milk yield as well as lowering its nutritive value (Patil et al., 2015). Therefore, the positive advancement of milk intake by consumers should be encouraged by the high quality of raw milk in dairy practice (Tancin, 2013). Mastitis is an inflammation of the mammary gland and udder tissue which can occur in clinical and Subclinical forms (Gonzales et al., 2008) and is characterized by physical, chemical, and bacteriological changes in the milk and pathological changes in the glandular tissue of the udder (Sharma et al., 2007). This disease negatively affects the physical-chemical characteristics, composition, and yield of milk (Cunha et al., 2008) and thus, it is essential to monitor intramammary infections (IMI) in dairy cows in order to maintain milk quality and herd health.

However, as IMI are usually followed by an influx of leucocytes into the milk, an increase in its somatic cell count (SCC) has been used widely as indicating mastitis (Hanan et al., 2015). SCC is a useful predictor of intramammary infection and, therefore, an important component of milk in assessment of aspects of quality, hygiene, and mastitis control (Patil et al., 2015). Individual somatic cell count is extensively available to dairy farmers and is also less expensive than microbiological culture (Schukken et al., 2003). There is considerable literature available suggesting the changes occur in milk composition and milk yield due to mastitis and increased SCC level in milk of different breeds of cows (Ballou et al., 1995; Kumaresan, 2013; Malek dos Reis et al., 2013) under different climatic conditions, but there is relatively limited information 
available in the literature on relationship between IMI, SCC and raw milk parameters in Jersey crossbred cows particularly under hot-humid climate.

Therefore, the present study was aimed to determine the relationship among intramammary infection and raw milk parameter in Jersey crossbred cows under hot-humid climate.

\section{MATERIALS AND METHODS}

\section{Animals and location}

To conduct the present study, twenty four lactating Jersey crossbred cows were randomly selected from the lactating herd of Cattle yard of Eastern Regional Station, ICARNational Dairy Research Institute located in Kalyani city of West Bengal. The altitude of Kalyani city is 9.75 meter above mean sea level, latitude and longitude position being $22^{\circ} 56^{\prime} 30^{\prime \prime} \mathrm{N}$ and $88^{\circ} 32^{\prime} 04^{\prime \prime} \mathrm{E}$, respectively and the weather of Kalyani is hot and humid.

\section{Collection of milk samples}

Representative animal wise morning milk samples were collected from all experimental lactating cows in monthly interval for four months of duration. For the analysis of milk fat and solid non-fat (SNF) along with SCC and milk $\mathrm{pH}$, about $100 \mathrm{ml}$ of pooled milk samples from all individual cows were collected aseptically and separately in the clean and sterilized sampling bottles. The collected samples were brought to the laboratory immediately for further analysis. Test day milk yield for individual animals was also recorded.

\section{Detection of IMI and classification of healthy and subclinical infected samples}

Intramammary infection was detected using microscopic method of somatic cell count (SCC). The dried milk smears stained with modified Newman's Lampert stain were examined under the oil immersion lens $(100 \mathrm{X})$ of the microscope. Thirty different fields per smear were observed and average number of cells per field was then multiplied by the microscopic factor of the microscope i.e. 240807 to obtain the number of cells per ml of the milk. Milk samples were classified into healthy or subclinical infected using threshold level of SCC as 2,00,000 /ml of milk. The samples having SCC $<2,00,000 / \mathrm{ml}$ of milk were considered as healthy while, samples having SCC $\geq$ $2,00,000 / \mathrm{ml}$ of milk were classified as subclinical infected samples.

Table 1. Correlation coefficients of $\log _{10} \mathrm{SCC}$ with test day milk yield (TDMY), fat (\%), SNF (\%) and $\mathrm{pH}$

\begin{tabular}{lc}
\multicolumn{1}{c}{ Traits } & Correlation coefficient \\
\hline $\log _{10} \mathrm{SCC}:$ test day milk yield & $-0.488^{* *}$ \\
$\log _{10} \mathrm{SCC}:$ fat $\%$ & $-0.337^{* *}$ \\
$\log _{10} \mathrm{SCC}: \mathrm{SNF} \%$ & $-0.563^{* *}$ \\
$\log _{10} \mathrm{SCC}: \mathrm{pH}$ & $0.793^{* *}$ \\
\hline
\end{tabular}

**Correlation is significant at the 0.01 level (2-tailed)

Table 2. Mean \pm SE of $\log _{10} \mathrm{SCC}$, test day milk yield (TDMY), fat $\%, \mathrm{SNF} \%$ and $\mathrm{pH}$ in Healthy and subclinical mastitis (SCM) infected group

\begin{tabular}{lccc} 
Parameters & Healthy & SCM infected & $\begin{array}{c}\text { Overall } \\
\text { Mean }\end{array}$ \\
\hline $\log _{10} \mathrm{SCC}$ & $4.911 \pm 0.042^{\mathrm{A}}$ & $6.021 \pm 0.070^{\mathrm{B}}$ & $5.489 \pm 0.070$ \\
TDMY & $8.413 \pm 0.477^{\mathrm{A}}$ & $5.570 \pm 0.466^{\mathrm{B}}$ & $6.932 \pm 0.362$ \\
Fat \% & $4.704 \pm 0.052^{\mathrm{A}}$ & $4.464 \pm 0.043^{\mathrm{B}}$ & $4.579 \pm 0.035$ \\
SNF\% & $8.898 \pm 0.032^{\mathrm{A}}$ & $8.628 \pm 0.016^{\mathrm{B}}$ & $8.757 \pm 0.022$ \\
pH & $6.634 \pm 0.009^{\mathrm{A}}$ & $6.837 \pm 0.020^{\mathrm{B}}$ & $6.740 \pm 0.015$ \\
\hline
\end{tabular}

Mean showing different superscripts in upper case letters in respective categories in a row differ significantly $(\mathrm{P}<0.01)$

\section{Estimation of milk parameters}

Among the milk parameters, milk fat, solid non-fat (SNF) and milk $\mathrm{pH}$ were estimated for individual samples. Individual milk samples pooled for all four quarters from the entire animal were used for estimation of fat $\%$ in milk by adapting Gerber's butyrometric method and milk SNF\% were determined by lactometer method using the ISI formula. The $\mathrm{pH}$ of milk samples were determined by an electronically operated digital $\mathrm{pH}$ meter with glass electrode. 


\section{Statistical analysis}

The SCC values were transformed into log scale to minimize the heterogeneity of variance and the data collected in this study were analysed by using SAS software package, version 9.3 (SAS Institute Inc., 2011).

\section{RESULTS AND DISCUSSION}

Correlation coefficients of $\log _{10} \mathrm{SCC}$ with different milk characteristics (test day milk yield (TDMY), fat (\%), SNF $(\%)$ and $\mathrm{pH}$ ) have been presented in table-1 and their mean \pm SE in healthy and sub clinically infected cows has been shown in table-2.

In the present study, test day milk yield (TDMY) was found to be significantly $(\mathrm{P}<0.01)$ negatively correlated $(-0.488)$ with the SCC level in milk and mean \pm SE of TDMY of healthy animal $(8.413 \pm 0.477 \mathrm{~kg})$ was significantly $(\mathrm{P}<0.01)$ higher than that of infected group $(5.570 \pm$ $0.466 \mathrm{~kg}$ ). Several previous studies have been shown that increased SCC is associated with reduction in milk yield (Jia-zhong et al., 2010; Guo et al., 2010; Kumaresan, 2013; Cinar et al., 2015), which are in consistent with present study. The decrease in milk yield might be due to physical damage to the epithelial cells of the affected mammary gland, and a consequent reduction in the synthetic and secretory capacity of the gland. Any retardation of the capacity of the mammary gland to synthesise and secrete lactose is of particular importance in this regard, given the key role of lactose as the osmotic regulator of milk volume (Auldist et al., 1998).

The results of the present study indicate that fat percentage tended to decrease with increase in somatic cell count in milk as we found significantly $(\mathrm{P}<0.01)$ negative correlation between fat percent in milk and $\log _{10} \mathrm{SCC}$ with correlation coefficient of -0.337 . The mean \pm SE fat percent was significantly $(\mathrm{P}<0.01)$ lower in infected animals $(4.464 \pm 0.043)$ as compared to healthy group (4.704 \pm $0.052)$. Other researcher have also been confirmed the similar relationship between fat content and SCC (Tahawy et al., 2010; Guo et al., 2010; Ghasemi et al., 2013). In contrast to present study, several researchers (Ouedraogo et al., 2008; Malek dos Reis et al., 2013; Kumaresan, 2013; Cinar et al., 2015) reported positive increase in fat content with increase in SCC level in milk. Gargouri et al. (2008) suggested that inflammatory cells, especially polymorph nuclear (PMN) cells could be responsible for sufficient lipolysis of milk fat globules.

The solid non-fat (SNF) content in milk was also found to be significantly $(\mathrm{P}<0.01)$ negatively correlated with the $\log _{10}$ SCC with correlation coefficient of -0.563 . The mean \pm SE SNF percent was $8.628 \pm 0.016$ and 8.898 \pm 0.032 , respectively for infected and healthy group. The negative correlation between SNF and SCC is well documented by many authors (Tahawy et al., 2010; Kumaresan, 2013; Malek dos Reis et al., 2013; Şahin and Kaşıkc1, 2014). A significantly $(\mathrm{p}<0.05)$ lower SNF in milk from cows infected with sub clinical mastitis as compared with milk from uninfected cows has been reported by Hassan (2013), decrease in SNF in infected cow's milk depend on the destroyed that occur by invasion of pathogens to the mammary tissue cause decrease in synthetic activity of mammary gland (BenChedly et al., 2009).

The findings of present study showed highly significant $(\mathrm{P}<0.01)$ positive correlation $(\mathrm{r}=0.793)$ between $\mathrm{SCC}$ and milk $\mathrm{pH}$ and $\mathrm{pH}$ tended to increase with increase in SCC. The mean $\mathrm{pH}$ value for healthy group was lesser (6.634 \pm 0.009$)$ as compared to subclinical infected group (6.837 \pm 0.020$)$, which is in agreement with the results of previous reports (Batavani et al., 2007; Hassan, 2013), whereas, negative relationship between $\mathrm{SCC}$ and milk $\mathrm{pH}$ has been reported by Atasever et al. (2010). These changes might be linked to the increase permeability of the mammary epithelium cell lead to the transfer of components from blood to milk such as citrates and bicarbonates that cause elevated $\mathrm{pH}$ levels (Harmon, 1994).

\section{CONCLUSION}

This investigation showed that the raw milk parameters are adversely affected by intramammary infection resulting in negative changes in milk yield, fat (\%) and SNF (\%) whereas, SCC and milk pH increased due to IMI. Thus, the marked changes in these raw milk parameters like milk yield, fat and SNF could be used as useful indicator of udder health condition as complimentary to SCC, which can be used along with $\mathrm{pH}$ test as direct index of intramammary infection and for early diagnosis of subclinical mastitis at dairy farm. 


\section{REFERENCES}

Auldist, M. J. and Hubble, I. B. 1998. Effects of mastitis on raw milk and dairy products. Aust. J. Dairy Tech., 53: 28-36.

Atasever, S., Erdem, H. and Altop, A. 2010. Relationships between milk somatic cell count and $\mathrm{pH}$ in dairy cows. $J$. Anim. Vet. Adv., 9 (11): 1575-1577.

Ballou, L. U., Pasquini, M., Bremel, R. D., Everson, T. and Dean, S. R. D. 1995. Factors affecting herd milk composition and milk plasmin at four levels of somatic cell counts. J. Dairy Sci., 78: 2186-2195.

Batavani, R. A., Asri, S. and Naebzadeh, H. 2007. The effect of subclinical mastitis on milk composition in dairy cows. Iran J. Vet. Res., 8: 205-211.

BenChedly, H., Boutinaud, M., Bernier-Dodier, P., Marnet, P. G. and Lacasse, P. 2009. Disruption of cell junctions induces apoptosis and reduces synthetic activity in lactating goat mammary gland. J. Dairy Sci., 93: 2938-2951.

Cinar, M., Serbester, U., Ceyhan, A. and Gorgulu, M. 2015. Effect of somatic cell count on milk yield and composition of first and second lactation dairy cows. Italian J. Anim. Sci., 14: $36-46$.

Cunha, R. P. L., Molina, L. R., Carvalho, A. U., FacuryFilho, E. J., Ferreira, P. M. and Gentilini, M. B. 2008. Subclinical mastitis and relationship between somatic cell countwith number of lactations, production and chemical composition of milk. Arq. Bras. Med. Vet. Zoo., 60: 19-24.

Gargouri, A., Hamed, H. and Feki, A. E. 2008. Total and differential bulk cow milk somatic cell counts and their relation with lipolysis. Livest. Sci., 113: 274-279.

Ghasemi, Z., Aslaminejad, A. A., Tahmoorespur, M., Rokouei, M. and Arough, M. F. 2013.Association of somatic cell score with production traits in Iranian Holstein cows. Iranian $J$. Appl. Anim. Sci., 3: 491-495.

Gonzales, L. A., Tolkamp, B. J., Coffey, M. P., Ferret, A. and Kyriazakis, I. 2008. Changes in feeding behaviour as possible indicators for the automatic monitoring of health disorders in dairy cows. J. Dairy Sci., 91: 1017-1028.

Guo, J. Z., Liu, X. L., Xu, A. and Xia, Z. 2010. Relationship of somatic cell count with milk yield and composition in Chinese Holstein population. Agric. Sci. China, 9(10): 14921496.

Hanan, M., El-Hewairy, Sahar, A., Galal, Hamouda, R. H. and Dohreig, R. M. A. 2015. Immunological and bacteriological findings associated with subclinical mastitis in dairy farm. Life Sci. J., 12(2): 139-146.

Harmon, R. J. 1994. Physiology of mastitis and factors affecting somatic cell count. J. Dairy Sci., 77: 2103-21120.

Hassan, H. J. 2013. Variations in milk composition of some farm animals resulted by sub-clinical mastitis in al-Diwania province. Bas. J. Vet. Res., 12: 2.

Jia-zhong, G., Xiao-lin, L., A-Juan, X. and Zhi, X. 2010. Relationship of somatic cell count with milk yield and composition in Chinese Holstein population. Agric. Sci. China, 9: 1492-1496.

Kumaresan, G. 2013. Somatic cell pattern and composition of milk of Holstein Friesian cross bred cattle. Int. J. Sci. Env. Tech., 2 (6): 1421 - 1425.

Malek dos Reis, C. B., Barreiro, J. R., Mestieri, L., Porcionato, M. A. and dos Santos, M. V. 2013. Effect of somatic cell count and mastitis pathogens on milk composition in Gyr cows. BMC Vet. Res., 9: 67.

Ouedraogo, G. A., Millogo, V., Anago-Sidibe, A. G. and Kanwe, B. A. 2008. Relationship between somatic cell counts, dairy cattle milk yield and composition in Burkina Faso. Afr. $J$. Biochem. Res., 2 (2): 56-60.

Patil, M. P., Nagvekar, A. S., Ingole, S. D., Bharucha, S. V. and Palve, V. T. 2015. Somatic cell count and alkaline phosphatase activity in milk for evaluation of mastitis in buffalo. Veterinary World, 8(3): 363-366.

SAS Institute Inc. (2011) SAS ${ }^{\circledR} 9.3$ System Options: Reference, Second Edition. Cary, NC: SAS Institute Inc.

Şahin, A. and Kaşıkcı, M. 2014. Relationships between somatic cell count and some raw milk parameters of Brown Swiss cattle. Turkish J. Agri. - Food Sci. Tech., 2(5): 220-223.

Sharma, N. 2007. Alternative approach to control intramammary infection in dairy cows- Review. Asian J. Anim. Vet. Adv., 2(2): 50-62.

Schukken, Y. H., Wilson, D. J., Welcome, F., Garrison-Tinofsky, L. and Gonzales, R. N. 2003. Monitoring udder health and milk quality using somatic cell counts. Vet. Res., 34: 579-596.

Tahawy, A. S. and Far, A. H. 2010. Influences of somatic cell count on milk composition and dairy farm profitability. Int. J. Dairy Technol., 63: 463-469.

Tancin, V. 2013. Somatic cell counts in milk of dairy cows under practical conditions. Slovak J. Anim. Sci., 46(1): 31-34. 